\title{
Testing Operating Performance of Chinese Listed Firms before and after Cross-border M\&As: The Role of Entrepreneurial Orientation
}

\author{
Se Chen ${ }^{\mathrm{a}, \mathrm{b}^{*}}$, Mingxian $\mathrm{Li}^{\mathrm{a}}$, Jun $\mathrm{Li}^{\mathrm{c}}$ \\ ${ }^{a}$ School of Economics, Hunan Agricultural University, Changsha 410128, China \\ ${ }^{\mathrm{b}}$ Department of Economics, University of Essex, Colchester CO4 3SQ, Essex, England \\ ${ }^{\mathrm{c}}$ Essex Business School, University of Essex, Colchester CO4 3SQ, Essex, England
}

\begin{abstract}
At a time when China encourages its firms to go overseas, especially to countries and regions involved in its "Belt and Road Initiative", and sets up a favorable domestic environment for innovation and entrepreneurship, this paper is a first trial looking along both the two dimensions to test whether Chinese firms' operating performance changes after cross-border merger and acquisition (CBM\&A) activities, using entrepreneurial orientation (EO) as a moderating factor. The paper combines data from Chinese listed firms' annual reports, Chinese stock market financial statements database and the Zephyr database from 2001 to 2015 to examine how acquirers' operating performance changes after CBM\&A activities using EO as a moderating factor. In order to test whether the results are affected by the stock market, this paper also defines abnormal return on equity (ROE) to detect abnormal operating performance. After these, the paper divides the sample into separate industry groups to see whether results will change. The results obtained for the whole sample show that the performance of Chinese listed firms is fluctuant after CBM\&As within the sample years. It increases one year after the acquisition but drops two years later and then follows an increasing trend again. The moderating factor of EO is not significant for the sample as a whole. However, after dividing the sample into separate industry groups, it becomes clear that different industries have their own characteristics. EO helps Chinese listed firms to adjust to the post-acquisition situation and even to improve their performance to some extent in the metal mining industry and the business services industry. When ROE is substituted with abnormal ROE, the results do not change much.
\end{abstract}

\section{Keywords}

Chinese listed firms; cross-border merger and acquisition; operating performance; entrepreneurial orientation

\footnotetext{
" Corresponding author at: School of Economics, Hunan Agricultural University, Changsha 410128, China

E-mail address: chense225@hotmail.com
} 


\section{Introduction}

During a period of over thirty years of reform and openness, China has attracted a large number of Multinational Corporations (MNCs) and a huge amount of Inward Foreign Direct Investment (IFDI) from various countries and regions. Particularly after China's accession to the World Trade Organization (WTO) in 2001, the process of opening up the Chinese economy received a further boost. For example, in 2002 China had IFDI of $\$ 53 \mathrm{~b}$ (UNCTAD, 2003), more than the USA's total IFDI.

Recently, Outward Foreign Direct Investment (OFDI) from multinational companies in developing countries has increased rapidly. According to the United Nations Conference on Trade and Development (UNCTAD) (UNCTAD, 2013b), these developing economies generate almost one third of global FDI outflow, continuing a steady upward trend. As a large, developing country, China is no exception to this trend. In 2008 global FDI fell by around 20\%, while outward FDI from China nearly doubled (Davies, 2009). According to UNCTAD (2011), outflows from China increased by more than $\$ 10$ billion and reached a historical high of $\$ 68$ billion in 2010, exceeding Japanese OFDI for the first time. As an important mode of entry into OFDI, the CBM\&A activities of Chinese firms have also increased over recent years. Based on information from the Global Cross-border Merger and Acquisition Report by UNCTAD (2013a), Chinese CBM\&As increased from $\$ 1.194$ billion in 2002 to $\$ 37.11$ billion in 2012 with an average annual growth rate of $41 \%$, covering 172 countries and regions of five continents. Most of the firms involved in Chinese CBM\&As are publicly-listed companies occupying leading positions in the domestic market. For example, Chinese Geely acquired Sweden-based Volvo Cars products and hold 100\% stake in the company; and Lenovo purchased IBM's PC business for $\$ 1.75$ billion and acquired the "Think" family group of products.

However, despite the rapid increase in the number of CBM\&As, there have been many cases of Chinese CBM\&A failure. For instance, after the merger between the TV and DVD operations of TCL and France's Thomson, they set up a joint venture company, TTE, but a serious integration problems after the merger exerted continuing heavy losses on the TCL group. Luedi (2008) examines 56 cases of Chinese firms' CBM\&As from 1995 to 2007 and finds that 56\% of Chinese CBM\&As fail to create value. Although Chinese firms have now gained considerable experience in CBM\&A activities, many firms are still wary of undertaking CBM\&A activities due to the challenges and difficulties that they may face. Companies have to make a detailed survey of target firms' financial and business operations, study the regional environment of the target firms' location and familiarize themselves with any relevant law regulations. All of these require good decision-making skills, financial strength, and experience of M\&A transactions and market operation from the acquirers. Therefore, cross-border M\&A activities are risky and complicated. Particularly in the case of CBM\&As in developing countries like China who prefer to make deals with developed countries, it is meaningful to study the performance of Chinese firms after undertaking CBM\&A activities and the key factors that affect the results.

There are two methods which are used to analyze the performance of acquirers. One involves using event-study methodology to calculate cumulative abnormal returns (CARs) of listed firms around a CBM\&A announcement. The assumption of this method is that the capital market is mature and the stock market is very efficient, so that stock returns of the listed firm surrounding the CBM\&A announcement day represent the value of the firm's future cash flow and an absence of restrictions on arbitrage. The event time window used in this method is very short, usually covering a few days before and after the announcement of a CBM\&A deal. The other method involves using some key financial indicators [such as ROE, return on assets (ROA), net income, earnings per share] to evaluate firms' performance. 
By examining the financial indicators of companies before and after the CBM\&As, we can assess how their business performance changes. As the datasets used in this paper are annual panel datasets and the Chinese capital market is still not efficient (i.e., stock prices are subject to manipulation and public policies are frequently changing), which means that stock prices cannot represent the change in shareholders' value nor stand for the company's performance, we use financial indicators to examine the long-term performance of Chinese listed firms involved in CBM\&A activities. This method may also have drawbacks, but the influence of possible financial manipulation is only temporary and thus the real impact of a CBM\&A will eventually be reflected in the long-term financial statements of the firm.

Unlike multinational companies (MNEs) from developed countries, the international operations of Chinese enterprises are still in their infancy. As their technological level and competitive ability still lag behind those of western countries, Chinese MNEs need to pay more attention to sustainable technological innovation and investment in order to improve their business performance and maintain rapid growth. According to Williams and Lee (2009), the definition of EO encompasses internal R\&D orientation which equates to technological innovation, and external asset growth orientation which represents investment. Moreover, a study on EO states that it can bring new opportunities and enhanced economic performance to international enterprises, making it easier for these positive, proactive MNEs to gain competitive advantages within the field of international operations because they are more willing to innovate and take risks in order to capitalize on potential expansion and profit opportunities (Lumpkin and Dess, 1996).Thus, it is interesting to quantify the EO based on the definition and theory above, in order to test whether EO can improve the performance of Chinese listed firms after CBM\&A activities. And the EO indicator is used as a moderating factor to examine whether or not it will help Chinese MNEs to improve their operating performance.

Therefore, in an environment where China promotes cooperation with countries and regions involved in its "Belt and Road Initiative", and meanwhile encourages innovation and entrepreneurship, this paper sees through both these two important phenomena and uses data from Chinese listed firms' annual reports, Chinese stock market financial statements database and the Zephyr database from 2001 to 2015 to examine the operating performance of Chinese listed firms which are involved in CBM\&A activities, and uses EO as a moderating factor to test whether it will affect the results. As well as testing firms comprising the whole sample from 2001 to 2015, this paper also explores subsample firms in different industry groups.

\section{Literature Review}

\subsection{CBMEA activities and the performance of acquirers}

The earliest paper we find considers the strategic motivation and performance of Chinese CBM\&A activities of 27 deals in the Shanghai and Shenzhen stock markets using data from 2000 to 2004 (Boateng et al., 2008). The researchers find that CBM\&As by Chinese firms are motivated by market development and indeed create value for Chinese acquiring firms. A more recent study uses data from 2000 to 2011 to examine the value creation for Chinese listed firms involved in CBM\&A activities and highlights the relationship between the cultural distance and the acquirers' market valuation (Li et al., 2016).

However, the literature shows complex findings for acquirers' financial performance after CBM\&A activities. For example, $\mathrm{Wu}$ and Xie (2010) use a sample of data for Chinese firms from 2000 to 2006 to measure CBM\&A performance, and they use the increase in rate of ROA as the dependent variable. 
The sample includes 91 Chinese acquirers, of which 61 are Chinese listed firms. After employing a multivariable linear regression model, they find that pre-acquisition performance and proportion of state-owned shares have a positive impact on the performance of acquiring companies. By contrast, Mei (2009) examines 36 samples of cross-border acquisitions undertaken by Chinese listed firms during the period from 2000 to 2007, and finds that the profit-making capability of Chinese listed firms drops after the CBM\&As occurs. In addition, the financial performance of these firms does not improve in the short term after the CBM\&As, although it improves slightly but not significantly in the second and third year after the CBM\&As. Using data from British firms, Dickerson et al. (1997) examine CBM\&As undertaken by British enterprises and find that there is no significant improvement in British acquirers' rates of profit. After comparing UK enterprises that have engaged in CBM\&A activities with other domestic firms, they find that the former yields a lower rate of return than enterprises which have only undertaken internal investment activities. Similarly, by studying 471 American corporations, Ravenscraft and Scherer (2011) find that their financial results after CBM\&A are poor.

Some scholars have examined acquirers in more than one country at the same time. By testing over a longer time period from 1981 to 1998, Gugler et al. (2003) use financial accounting data from various developed countries (the US, the UK, Japan, Australia, New Zealand, Canada, etc.) to compare enterprises which have engaged in CBM\&A activities with other firms that do not undertake CBM\&A activities. The results show that one to five years after CBM\&As, the profits of these firms increase but their sales decrease. After subdividing the acquirers into small and large firms, they find that the profits of both types increase significantly, but large firms' sales clearly decrease while small firms' sales increase. They claim that this is because small firms achieve economies of scale and scope after CBM\&As, while large firms enhance their market power and improve the extent of their monopoly through CBM\&As.

Therefore, the results of the post-CBM\&A operating performance are ambiguous. Based on Martynova and Renneboog (2008) which concludes that using cash-flow-based metrics yields positive returns but earning-based methods result in a negative performance in the case of CBM\&As, we decide to use information and data from Chinese listed firms for the period from 2001 to 2015 to test the performance of those involved in CBM\&A activities to see which studies will be supported.

\subsection{EO and the performance of acquirers}

EO is an important concept connected with entrepreneurship, which is first clarified by Lumpkin and Dess (1996). EO describes how entry into a new market is undertaken, that is, the processes, practices and decision-making activities that lead to companies entering new or established markets with new or existing services or goods via internal corporate venturing. Williams and Lee (2009) develop a new typology of MNCs' EO based on a two-dimensional view: longer-term technological development and shorter-term asset growth. Knight (2001) studies the relationship between small and medium enterprises' (SMEs) performance and international EO. He finds that EO could help firms to prepare their international strategy much more effectively. When resources are relatively scarce, enterprises are more likely to improve their technical and strategic ability, which plays a positive role in the promotion of enterprises' international business performance. In addition, Wiklund and Shepherd (2003) suggest that knowledge-based resources (i.e. ability to discover and exploit opportunities) are positively related to firm performance and that EO enhances this relationship. Additionally, Jantunen et al. (2005) explore the effect of EO and firms' reconfiguring capabilities on international performance based on survey data from 217 manufacturing and service organizations in Finland. The results indicate that a firm's entrepreneurial 
behavior combined with its reconfiguring capabilities has a substantial effect on international performance and constitutes a potential source of competitive advantage. However, another study on 98 international enterprises based in America shows that EO can improve a firm's performance but there is an upper limit to how much. Excessive pursuit of a high level of international EO does not necessarily ensure that enterprises can achieve a better performance (Zahra and Garvis, 2000).

Based on the literature discussed above, we use a two-dimensional method and quantify the EO according to the definition to measure Chinese listed firms' EO and set it as a moderating variable to test whether, and if so how, a firm's degree of EO affects its performance through CBM\&A deals.

\subsection{Other factors that may affect the performance of acquirers}

Firstly, an enterprise's organizational characteristics are widely believed to be an important influence on the outcome of learning and knowledge exchange, which in turn affects an international firm's strategies. Therefore, this suggests that the age, size and degree of prior international experience of an acquirer may affect the impact of the firm's performance.

Older firms tend to rely on the existing development pattern and get used to a path-dependent way of making decisions, which prevent them from exploring new technologies, new markets and innovating in general (Ahuja and Morris, 2001). However, younger firms are more likely to adopt aggressive strategies, exploring new business opportunities and absorbing new ideas. Thus, the younger the company, the more likely it will be to get involved in CBM\&A activities. Therefore, we use an acquirer's age as the first control variable in the models.

The size of an MNC is a double-edged sword. On the one hand, the larger the corporation, the more likely it is to be exposed to multiple opportunities which can form the basis of new entrepreneurial initiatives. On the other hand, larger and more diverse MNCs will have a reduced capability to implement efficient procedures for coordinating knowledge flows and combinations, and response times may be too long to keep pace with changes in markets (Hedlund, 1986). Therefore, an acquirer's size is used as the second control variable.

Normally a firm with a higher degree of prior international experience will have more experience of international business. However, a firm that has too many business networks with different countries has to spend more time smoothing internal knowledge coordination in order to operate effectively. The more international an MNC is, the more time it needs to spend on coordination. Eriksson et al. (1997) show that the degree of prior international experience is positively associated with the cost of collecting, transferring and decoding knowledge from overseas locations. Conversely, a less internationalized firm will be more eager to explore a new country and to view global expansion as an economic and strategic opportunity, rather than a costly risk (Shenkar and Luo, 2008). In particular, foreign investments by emerging economy firms lead to upgrade of their governance capabilities (Bhaumik et al., 2019). Consequently, international experience in terms of prior cross-border investments is used as the third control variable.

Secondly, we consider how corporate governance may affect a firm's performance and strategy. The top management team (TMT) in an MNC is the main component of corporate governance. High level managers' ideas, skills, experience, personal preferences and ability to implement change will affect a firm's strategy. Employees' perceptions of visionary leadership can act as a mediator, and the alignment in the vision/values/beliefs of the CEO with those of the shareholders can act as moderators (Fornes $e t$ al., 2019). In this paper, we use two characteristics (age and shared ownership) of the TMT as the fourth and fifth control variables. 
Based on the learning theory, older managers find it more difficult to absorb new ideas and new information and they tend to be more risk averse and behaviorally rigid with regard to strategic decisionmaking (Hambrick and Fukutomi, 1991). By contrast, younger managers prefer to undertake venture investment and are less likely to worry about failure. Hence, the older the TMT, the more likely it is that the MNC will be more conservative.

From principal-agent theory we know that top managers need to be stimulated by risk income in order to prompt them to make decisions which will enhance a firm's profit maximization. Giving top managers a larger stake in productivity can bring their private interests into alignment with the company's interests which will then constitute part of an internal entrepreneurial climate (Jensen and Murphy, 1990). Hence, the greater the degree of shared ownership allowed by a TMT in an MNC, the more it will encourage increased participation in exploiting new opportunities and adopting a relatively aggressive strategy to improve the firm's international business performance.

Finally, cultural distance is usually cited as an obstacle to learning in CBM\&A activities (Datta and Puia, 1995). Because of the communication costs, cultural difference makes it more difficult to share information and exchange knowledge between the acquirer and the target enterprise. A recent study also shows that crossborder flow of knowledge is affected by the nature and characteristics of the knowledge as well as the interaction between individual actor-specific, firm-specific and country-specific factors. The complexity associated with the organization of multinational companies and the information asymmetry in foreign locations pose particular challenges to knowledge flow (Gaur et al., 2019). Therefore, the degree of cultural proximity will influence the success of a firm's international business. Hence, cultural distance is the final control variable. Thus, based on all the studies discussed above, the research framework of this paper is summarized in Figure 1.

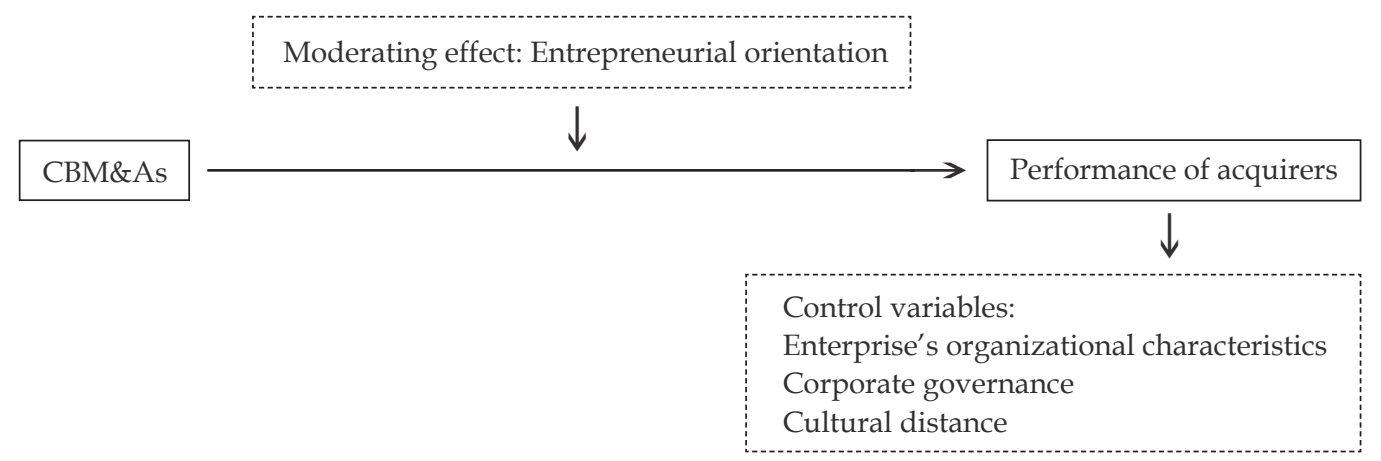

Fig. 1 Research framework

\section{Data and Methods}

\subsection{Sample and data}

We combine three datasets in the study. The first dataset is the CSMAR China Stock Market Financial Statements Database, which is one of the most authoritative databases of Chinese listed firms. All the information about the firms is obtained from the Shanghai and Shenzhen stock exchange reports. We collect data from 2001 to 2015 comprising firms' financial balance sheet, profit statement and cash flow statement. The CBM\&A information about each Chinese listed firm is taken from the Zephyr database. The target firms are located in different countries and their M\&A activities cover different industry sectors such as high-tech, low-tech and service industry. And the information about organizational characteristics and corporate governance are taken from Chinese listed firms' annual reports from 2001 to 2015. 
Based on the data from 2001 to 2015, there were 202 completed CBM\&A deals by Chinese listed firms (Table 1) in these years. According to the standard dataset by UNCTAD, the acquirers held a stake of more than $10 \%$ in the target firm in each completed deal. Some firms were involved in more than one deal during this period, and therefore there were 145 Chinese listed firms in total involved in CBM\&A activities. There were 39 target regions in total, of which the first five were Germany, Hong Kong, the US, Singapore and Canada (Figure 2). Under the US Standard Industrial Classification (SIC), target firms can be divided into 36 industries according to a two-digit SIC code. The top six industries cover $57 \%$ of the total sample (Figure 3) including Industrial and Commercial Machinery and Computer Equipment (15\%), Electronic and Other Electrical Equipment and Components (15\%), Chemicals and Allied Products (10\%), Primary Metal Industries (6\%), Business Services (6\%) and Transportation Equipment (5\%).

Table 1 Number of deals completed in each year

\begin{tabular}{|c|c|c|c|c|c|c|c|c|c|c|c|c|c|}
\hline 2002 & 2003 & 2004 & 2005 & 2006 & 2007 & 2008 & 2009 & 2010 & 2011 & 2012 & 2013 & 2014 & 2015 \\
\hline 1 & 9 & 7 & 8 & 4 & 9 & 15 & 14 & 14 & 19 & 18 & 22 & 33 & 29 \\
\hline
\end{tabular}

Source: Annual reports and Zephyr database

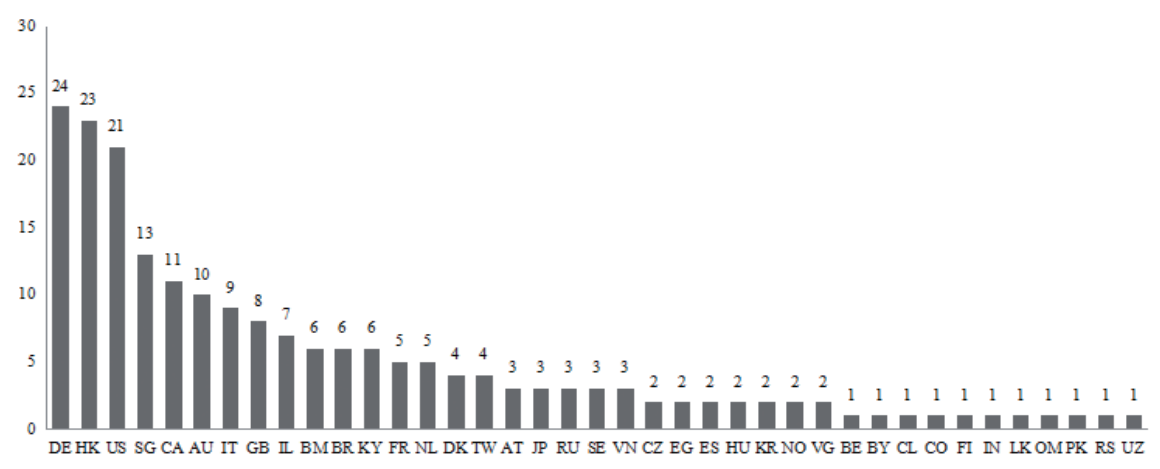

Fig. 2 Number of CBM\&A deals by Chinese listed firms with each target region Note: The numbers on the vertical axis represent numbers of CBM\&A deals Source: Annual reports and Zephyr database

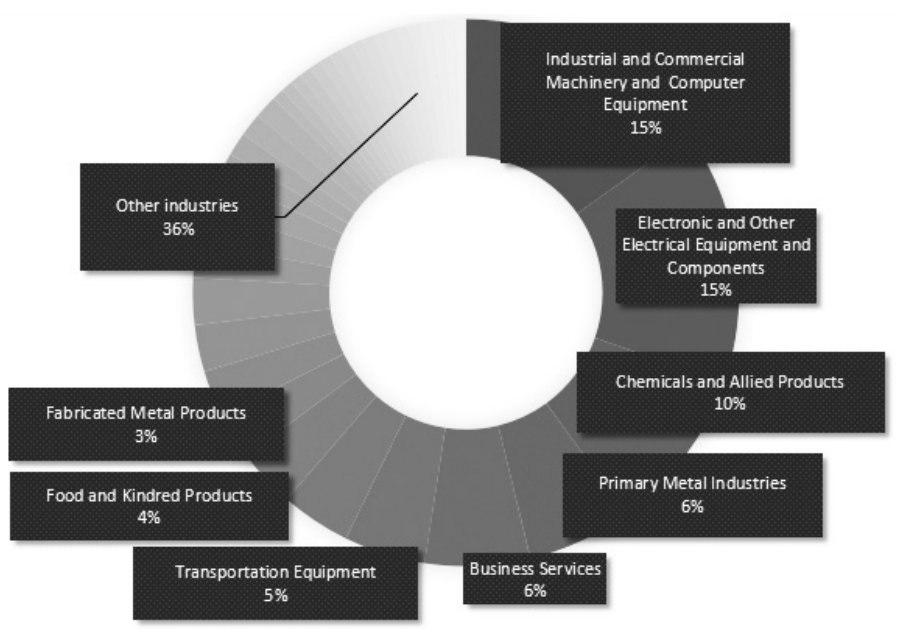

Fig. 3 The distribution of target industries Source: Zephyr database 


\subsection{Variables and models}

The assumption of the 'event study' methodology (which is known as a short-term study) is that the capital market is mature and the stock market is very efficient and the dataset used is cross-sectional data, however the Chinese capital market is still not efficient, which means that stock prices cannot represent the change in shareholders' value nor stand for the company's performance. Thus we use an accounting analysis method to examine the long-term performance of Chinese listed firms involved in CBM\&A activities. Based on the datasets we have obtained, we choose ROE, which has been widely used as the main index with which to judge the performance of a firm, especially for listed firms, as the financial indicator. Moreover, in the Chinese security market, ROE is used as one of the criteria to determine whether a firm should be specially treated or allowed to issue additional stock.

$$
\text { Return on Equity }(R O E)=\text { Net Income / Average Shareholders' Equity }
$$

The equation tells shareholders how efficiently their money is being utilized. In other words, ROE measures the efficiency of a firm's own capital operation and reflects the shareholders' equity return level.

Firstly we test the average trends of ROE based on the completed deal year (Figure 4). We divide the firms into groups by the year in which the CBM\&A activities happened and observe the trends by examining ROE levels during seven periods of time, namely the three years prior to the CBM\&As $\left(\mathrm{T}_{-1}, \mathrm{~T}_{-2}\right.$ and $\left.\mathrm{T}_{-3}\right)$, the year of the CBM\&As $\left(\mathrm{T}_{0}\right)$, and the three years after the CBM\&As $\left(\mathrm{T}_{1}, \mathrm{~T}_{2}\right.$ and $\left.\mathrm{T}_{3}\right)$.

We apply a regression to levels of ROE three years before and three years after the CBM\&As occur. The regression model is shown below, in which $M A$ is a dummy variable and $M A$ is equal to 1 if the firm engages in CBM\&A activity in a year. $M A_{t+i}$ is a dummy variable and it is equal to 1 if the year is $i$ years after the CBM\&A event year (such as $M A_{t+3}, M A_{t+2}$ and $M A_{t+1}$ ). Similarly, $M A_{t-i}$ is a dummy variable and it is equal to 1 if the year is $i$ years before the CBM\&A event takes place (such as $M A_{t-3}$, $M A_{t-2}$ and $\left.M A_{t-1}\right)$. The coefficients of this model are shown in Figure 4 which illustrates the average $R O E$ trends. Most of these coefficients are significant except the results of $M A$ and $M A_{t+2}$ (standard errors and significant levels of regression results are also shown in Figure 4). The descriptions of the variables are provided in Table 2 .

$$
R O E=\mathrm{b}_{1} M A_{t+3}+\mathrm{b}_{2} M A_{t+2}+\mathrm{b}_{3} M A_{t+1}+\mathrm{b}_{4} M A+\mathrm{b}_{5} M A_{t-1}+\mathrm{b}_{6} M A_{t-2}+\mathrm{b}_{7} M A_{t-3}+\xi_{i}
$$

Table 2 Descriptions of ROE CBM\&A dummy variables

\begin{tabular}{|c|c|c|c|c|c|}
\hline Variable & Obs & Mean & Std. Dev. & Min & Max \\
\hline ROE & 364 & 0.1024 & 0.284732 & -2.88385 & 2.075581 \\
\hline$M A_{t+3}$ & 364 & 0.1428 & 0.3504 & 0 & 1 \\
\hline$M A_{t+2}$ & 364 & 0.1429 & 0.3504 & 0 & 1 \\
\hline$M A_{t+1}$ & 364 & 0.1429 & 0.3504 & 0 & 1 \\
\hline$M A$ & 364 & 0.1429 & 0.3504 & 0 & 1 \\
\hline$M A_{t-1}$ & 364 & 0.1429 & 0.3504 & 0 & 1 \\
\hline$M A_{t-2}$ & 364 & 0.1429 & 0.3504 & 0 & 1 \\
\hline$M A_{t-3}$ & 364 & 0.1429 & 0.3504 & 0 & 1 \\
\hline
\end{tabular}




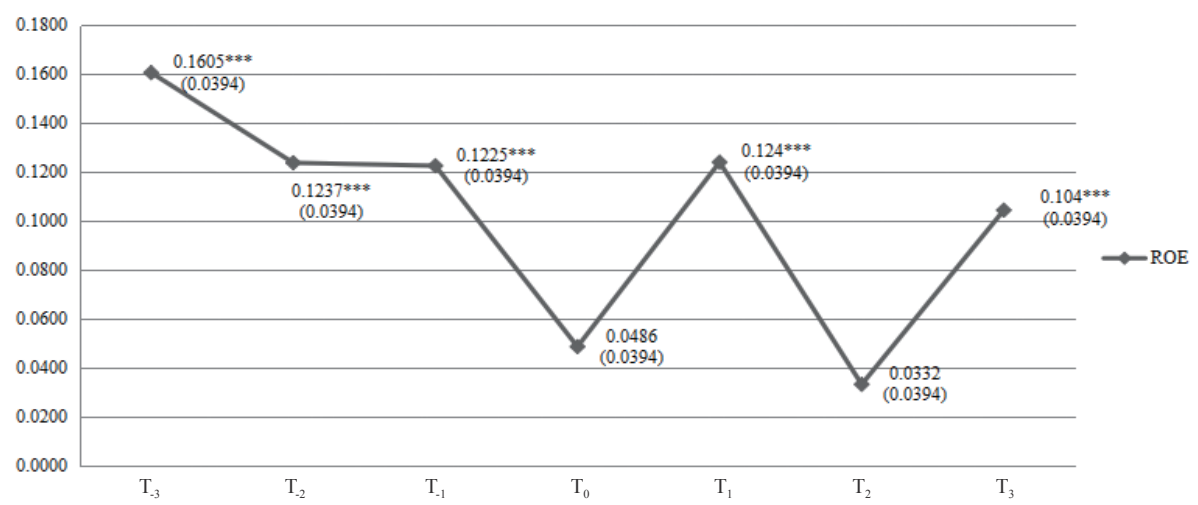

Fig. 4 Average ROE trends of sample deals

Note: Standard errors in parentheses, ${ }^{* * *} \mathrm{p}<0.01,{ }^{* *} \mathrm{p}<0.05,{ }^{*} \mathrm{p}<0.1$

From the graph above it can clearly be seen that the average $R O E$ declined from $\mathrm{T}_{-1}$ to $\mathrm{T}_{0}$. We can see that in the first year after a CBM\&A, the average ROE increases slightly. Then, in the second year after a CBM\&A, the average ROE declines gradually. Three years after a CBM\&A, the average ROE increases to a level higher than the rate in the acquisition year. This phenomenon suggests that it will take listed firms two years to adjust after a CBM\&A takes place before they can improve their performance.

Next, paired sample t-tests and Wilcoxon sign-rank tests are conducted (Table 3) based on Barber and Lyon (1996). A paired sample t-test is used to discover whether the means of the normally distributed interval variables in two time periods (such as before and after CBM\&As) differ from one another. The Wilcoxon sign-rank test is the non-parametric version of a paired sample t-test, which releases the assumption that the difference between two paired variables is interval and is normally distributed.

Table 3 ROE paired sample t-test and Wilcoxon sign-rank test

\begin{tabular}{|c|c|c|c|c|c|c|}
\hline & \multicolumn{3}{|c|}{ Paired Differences } & \multirow[b]{2}{*}{$\mathrm{t}$} & \multirow[b]{2}{*}{ Sig.(2-tailed) of t-test } & \multirow[b]{2}{*}{ Wilcoxon's p } \\
\hline Paired samples & Mean & Std. Err. & Std. Dev. & & & \\
\hline $\mathrm{T}_{0}-\mathrm{T}_{-3}$ & -0.1119 & 0.0603 & 0.4347 & -1.856 & $0.0692^{*}$ & 0.3121 \\
\hline $\mathrm{T}_{0}-\mathrm{T}_{-2}$ & -0.0751 & 0.0539 & 0.3892 & -1.3911 & 0.1702 & $0.0699 *$ \\
\hline $\mathrm{T}_{0}-\mathrm{T}_{-1}$ & -0.0739 & 0.0540 & 0.3896 & -1.3674 & 0.1775 & $0.0461^{* *}$ \\
\hline $\mathrm{T}_{1}-\mathrm{T}_{0}$ & 0.0753 & 0.0756 & 0.5453 & 0.9958 & 0.3240 & 0.2474 \\
\hline $\mathrm{T}_{2}-\mathrm{T}_{0}$ & -0.0153 & 0.0301 & 0.2173 & -0.5110 & 0.6116 & 0.1528 \\
\hline $\mathrm{T}_{3}-\mathrm{T}_{0}$ & 0.0557 & 0.0723 & 0.5217 & 0.7701 & 0.4448 & $0.0309 * *$ \\
\hline $\mathrm{T}_{1}-\mathrm{T}_{-3}$ & -0.0365 & 0.0508 & 0.3662 & -0.7201 & 0.4748 & 0.1777 \\
\hline $\mathrm{T}_{1}-\mathrm{T}_{-2}$ & 0.0002 & 0.0375 & 0.2709 & 0.0062 & 0.9951 & $0.0323^{* *}$ \\
\hline $\mathrm{T}_{1}-\mathrm{T}_{-1}$ & 0.0014 & 0.0363 & 0.2619 & 0.0396 & 0.9686 & $0.0212^{* *}$ \\
\hline $\mathrm{T}_{2}-\mathrm{T}_{-3}$ & -0.1273 & 0.0683 & 0.4927 & -1.862 & $0.0682^{*}$ & $0.0743^{*}$ \\
\hline $\mathrm{T}_{2}-\mathrm{T}_{-2}$ & -0.0905 & 0.0616 & 0.4442 & -1.4686 & 0.1481 & $0.0053^{* * *}$ \\
\hline $\mathrm{T}_{2}-\mathrm{T}_{-1}$ & -0.0892 & 0.0629 & 0.4539 & -1.4182 & 0.1622 & $0.0150^{* *}$ \\
\hline $\mathrm{T}_{3}-\mathrm{T}_{-1}$ & -0.0182 & 0.0342 & 0.2465 & -0.5310 & 0.5977 & $0.0021^{* * *}$ \\
\hline $\mathrm{T}_{3}-\mathrm{T}_{-2}$ & -0.0194 & 0.0353 & 0.2543 & -0.5488 & 0.5855 & $0.0080^{* * *}$ \\
\hline $\mathrm{T}_{3}-\mathrm{T}_{-3}$ & -0.0562 & 0.0499 & 0.3599 & -1.1250 & 0.2659 & $0.0582^{*}$ \\
\hline
\end{tabular}

Note: ${ }^{* * *} \mathrm{p}<0.01,{ }^{* *} \mathrm{p}<0.05,{ }^{*} \mathrm{p}<0.1$ 
The results show that significant changes in $R O E$ reflect the efficiency of a firm's own capital operation and the shareholders' equity return level. More significant results of changes in ROE under the Wilcoxon sign-rank test are displayed in Table 3, which indicates that the difference between two paired variables is not interval and normally distributed. This result is consistent with the study by Barber and Lyon (1996), which finds that the Wilcoxon signed-rank test is more powerful than parametric t-statistics when detecting operating performance. Therefore, we can conclude that CBM\&A activities can have a significant impact on some aspects of a listed firm's financial performance but the effect is fluctuant and the firm needs time to adjust after CBM\&A activities have taken place. Moreover, in our case, the effect of CBM\&As on the listed firms' ROE is not guaranteed to be ultimately positive in the years after the CBM\&As.

Therefore, we establish regression models using the firms' $R O E$ as a dependent variable to test whether CBM\&A activities will have effects on firms' operating performance after CBM\&A activities. The independent variable is a dummy variable called PMA, which is equal to 1 at the time when the CBM\&A takes place and during the periods after this event, but is 0 otherwise.

The control variables include the acquirer's age (AGE), the acquirer's size (SIZE), degree of prior international experience (INT), the age of the TMT (TMTA), stock option (TMTSO), and cultural proximity (GCS). The acquirer's age is calculated as the year when the CBM\&A is completed minus the year of establishment. The acquirer size is calculated as the natural logarithm of the firm's total assets. The degree of prior international experience is the proportion of overseas business revenue divided by the total annual main business revenue. The TMT age is the average age of the TMT. The stock option is obtained by dividing the number of shares owned by the TMT by the total number of shares that the company holds at the end of the financial year. Finally, although the Cultural Difference index (CD index) created by Kogut and Singh (1988) is commonly used by scholars, this method has been criticized in recent years (Shenkar, 2001, 2012), because durable social connections and networks are not included in the CD indexes. Hence, we use the Greater China plus Singapore Dummy (GCS) to control for cultural proximity based on Li et al. (2016). Cultural proximity is coded as 1 if the target company is located in the Confucian cultural circle, and 0 otherwise. Therefore, the initial regression model is:

$$
R O E_{i t}=\mathrm{a}+\mathrm{b}_{0} P M A_{i t}+\mathrm{b}_{1} A G E_{i t}+\mathrm{b}_{2} \operatorname{SIZE}_{i t}+\mathrm{b}_{3} I N T_{i t}+\mathrm{b}_{4} T_{M T A_{i t}}+\mathrm{b}_{5} T_{M T S O}+\mathrm{b}_{6} G C S_{i t}+\xi_{i t}
$$

We then add the moderating variable EO. According to Williams and Lee (2009), one way to pursue entrepreneurship is through internal corporate venturing and, in this regard, it is important for the company's R\&D department to identify new business opportunities. Another way of pursuing entrepreneurship in an MNC is to exploit its "deep pockets", which means taking advantage of external investment opportunities. Therefore, the notion of MNCs' EO can be applied through two dimensions, and activities in this area can take the MNC in new directions, although it will involve entrepreneurial risks. The two-dimensional EO space is shown in Figure 5. If we set the longer-term internal R\&D dimension as the $Y$-axis and the shorter-term external asset growth dimension as the $X$-axis, we can then divide MNCs into four types based on combinations of the EO dimensions. The arrows indicate the increasing risk and depth of resource allocation to entrepreneurship, which can be categorized as follows: conservative MNCs; internal R\&D aggressive MNCs; external asset growth aggressive MNCs; and mixed aggressive MNCs. 


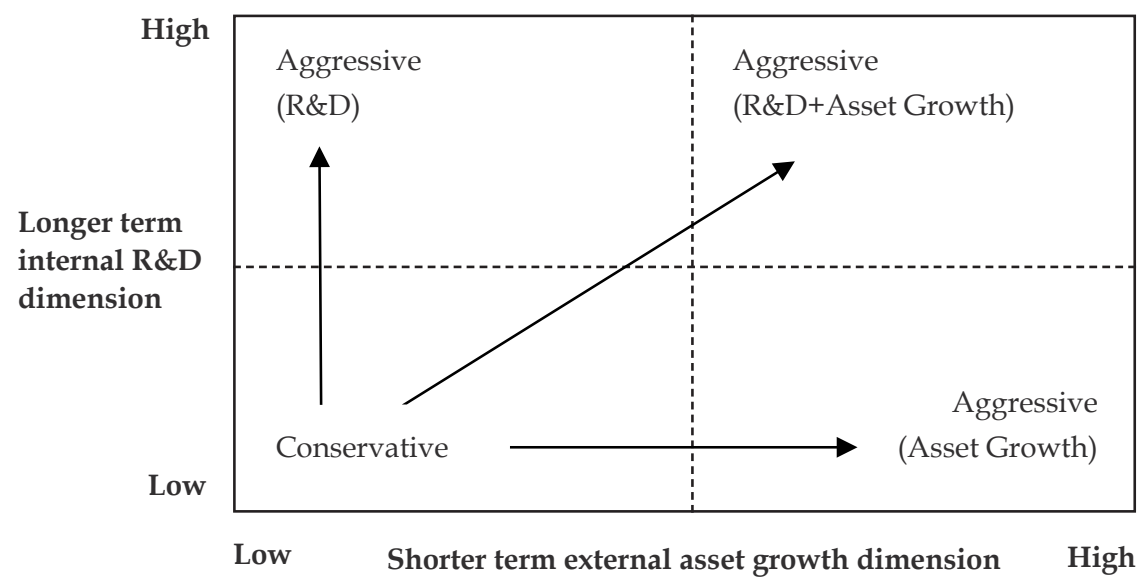

Fig. 5 Two dimensional typology of Multinational Corporations' entrepreneurial orientation Note: Vertical axis is the longer-term internal R\&D dimension and horizontal axis is the shorterterm external asset growth dimension

Therefore, the internal R\&D direction which emphasizes longer-term proprietary technology development is defined as $R \& D$ intensity ( $\&$ D spending as a ratio of sales). The external asset growth direction which focuses on shorter-term investments is defined as investment intensity (the sum of investment activities on the cash flow statement as a ratio of sales). Then, in the two-dimensional space, the Euclidean distance is used to calculate the EO intensity of the Chinese listed firm's investment position from the origin $(0,0)$. We treat $(0,0)$ as the most conservative position, i.e., the closer the firm is to the origin $(0,0)$, the more conservative it is, and the further the firm is from the origin $(0,0)$, the more aggressive it is. One thing needs to be pointed out is that although the $E O$ definition is completed by using this method to measure, this method cannot figure out the different structures of Research and Development intensity $(R D I)$ and investment intensity (II) of different companies. For example, if the first company's position is $(1,0)$ which means $R D I=1$ and $I I=0$, and the second company's position is $(0,1)$ which means $R D I=0$ and $I I=1$, by using Euclidean distance to measure $E O$, they can get the same degree of $E O$. But actually the structure of them is different.

$$
E O_{i}=\sqrt{R D I^{2}+I I^{2}}
$$

We plot a scatter gram of the RDI and II of the Chinese listed firms in the whole sample from 2001 to 2015, in which each black dot refers to each firm's EO position in a specific year (Figure 6). Therefore, the linear distance between each dot and the origin $(0,0)$ is this firm's $E O$ intensity in one year of the sample. It can be seen that most of the Chinese listed firms in the sample are relatively conservative because most of them are clustered near the origin point, and a firm which has a relatively high II has a low R\&D intensity $(R D I)$ and vice versa because most of the dots are close to the $X$-axis or $Y$-axis. For the sample as a whole, $4.09 \%$ of the firms are internal R\&D aggressive (II is equal to 0 ), $56.86 \%$ are external asset growth aggressive ( $R D I$ is equal to 0 ), $14.23 \%$ are mixed aggressive (both $R D I$ and $I I$ are not equal to 0 ) and $24.82 \%$ are extremely conservative (both RDI and II are equal to 0 ). As the RDI and II of each firm change in subsequent years, the firm's type of $E O$ also changes. In other words, a firm could be extremely conservative in 2001 and then become internal R\&D aggressive in 2002 but go on to become external asset growth aggressive in 2005 and mixed aggressive some years later. 


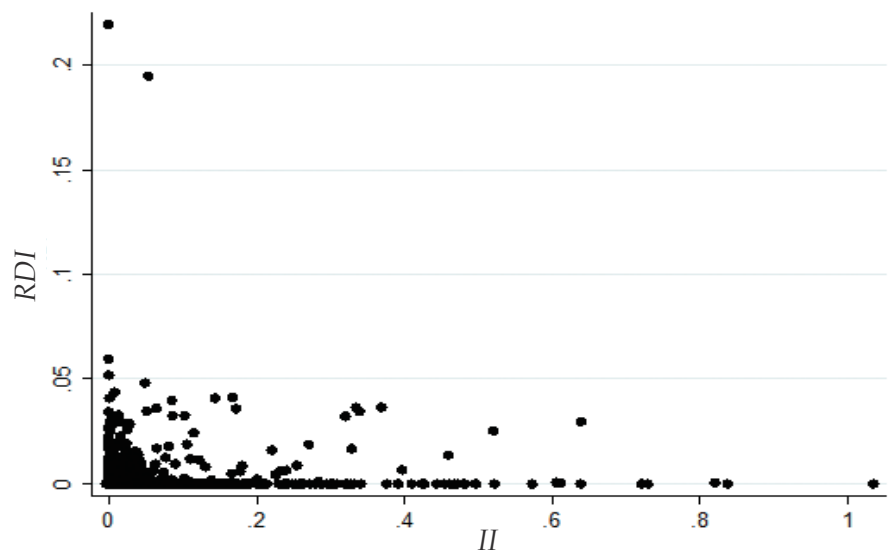

Fig. 6 Scatter gram of two-dimensional $E O$ of Chinese listed firms for the whole sample

Note: Numbers on the vertical axis represent R\&D intensity $(R D I)$ and numbers on the horizontal axis represent investment intensity $(I I)$

According to Sharma et al. (1981), a moderating variable is one which specifies the magnitude and/ or form of the relationship between a dependent variable and an independent variable. A moderating variable can be developed by two characteristics: whether it is related to the dependent variable; and whether it interacts with the independent variables. Therefore, the regression model with variable $E O$ is:

$$
R O E_{i t}=\mathrm{a}+\mathrm{b}_{0} P M A_{i t}+\mathrm{b}_{1} E O_{i t}+\mathrm{b}_{2} E O_{i t}{ }^{*} P M A_{i t}+\mathrm{b}_{3} A G E_{i t}+\mathrm{b}_{4} S I Z E_{i t}+\mathrm{b}_{5} I N T_{i t}+\mathrm{b}_{6} T M T A_{i t}+\mathrm{b}_{7} T M T S O_{i t}+\mathrm{b}_{8} G C S_{i t}+\xi_{i t}
$$

\section{Results and Robustness Tests}

Table 4 shows summary statistics of the variables taken from the annual dataset. The panel comprises the number of sample firms multiplied by the number of years after they become listed until 2015. Table 5 represents the correlation matrix of the independent variables, moderating variables and control variables. $E O$ is found to be positively correlated with the TMT's stock option (0.0517), which is consistent with the finding in the literature that giving top managers a larger stake in productivity prompts them to make more ambitious decisions in order

Table 4 Summary of variables

\begin{tabular}{|c|c|c|c|c|c|}
\hline Variables & Obs. & Mean & Std. Dev & Min & Max \\
\hline$R O E$ & 1567 & 0.0860 & 0.3098 & -2.8838 & 5.7999 \\
\hline$P M A$ & 1567 & 0.4627 & 0.4988 & 0 & 1 \\
\hline$E O$ & 1567 & 0.0411 & 0.0920 & 0 & 1.0336 \\
\hline Acquirer Age & 1567 & 12.8086 & 5.3528 & 1 & 32 \\
\hline Acquirer Size & 1567 & 8.1525 & 1.4973 & 1.0986 & 13.0032 \\
\hline Degree of prior international experience & 1567 & 0.2094 & 0.2730 & 0 & 1 \\
\hline TMT Age & 1567 & 47.9567 & 3.9363 & 33.4 & 60 \\
\hline TMT Stock Option & 1567 & 0.0399 & 0.1144 & 0 & 0.8942 \\
\hline
\end{tabular}

Source: Annual reports and Zephyr database 
Table 5 Correlations between independent variables

\begin{tabular}{|c|c|c|c|c|c|c|c|c|}
\hline & $P M A$ & $E O$ & $\begin{array}{c}\text { Acquirer } \\
\text { Age }\end{array}$ & $\begin{array}{c}\text { Acquirer } \\
\text { Size }\end{array}$ & $\begin{array}{c}\text { Degree of } \\
\text { INT }\end{array}$ & TMT Age & TMTSO & GCS \\
\hline PMA & 1 & & & & & & & \\
\hline EO & 0.0411 & 1 & & & & & & \\
\hline Acquirer Age & $0.3489^{*}$ & -0.01 & 1 & & & & & \\
\hline Acquirer Size & $0.2676^{*}$ & -0.0114 & 0.0336 & 1 & & & & \\
\hline $\begin{array}{c}\text { Degree of prior } \\
\text { international } \\
\text { experience }\end{array}$ & $0.1402^{*}$ & -0.0157 & 0.0104 & $0.0814^{*}$ & 1 & & & \\
\hline TMT Age & $0.1882^{*}$ & 0.0423 & $0.3284^{*}$ & $0.2087^{*}$ & $-0.1078^{*}$ & 1 & & \\
\hline TMT Stock Option & -0.01 & $0.0517^{*}$ & $-0.0646^{*}$ & $-0.1071^{*}$ & 0.0375 & $-0.1646^{*}$ & 1 & \\
\hline $\begin{array}{c}\text { Greater China plus } \\
\text { Singapore Dummy }\end{array}$ & $0.3336^{*}$ & 0.0252 & $0.1783^{*}$ & -0.0138 & $0.1187^{*}$ & $0.0887^{*}$ & 0.0156 & 1 \\
\hline
\end{tabular}

Note: Correlations in magnitude with an asterisk * are significant at the $\mathrm{p} \leq 0.05$ level of confidence

to maximize a firm's profit. As the correlations between variables are not high $(<0.35)$ for this dataset, according to previous studies of collinearity (Mason et al., 1991), multicollinearity is not a problem for the independent, moderating and control variables used here, and therefore need not be a major concern for this study.

Using the annual data from 2001 to 2015 to test the total effects of Chinese listed firms' operating performance after CBM\&A, we find that the total effect of $R O E$ is significantly negative, and, after adding the moderating variable $E O$, the result does not change much. Therefore, the moderating effect generated by $E O$ is not significant. As stated in the literature review, the findings regarding postCBM\&A operating performance are ambiguous, and Martynova and Renneboog (2008) conclude that using cash-flow-based metrics produces positive returns but earning-based methods results in a negative performance in the case of CBM\&As. Thus, the negative effects on ROE in column (1) and (2) of Table 6 support their conclusion, based on the fact that ROE showed the earnings of a corporation raised from shareholders.

The results of the control variables from two regressions also show some of the factors that affect firms' CBM\&A performance. From a corporate governance perspective, the acquirer size is significantly positively related to $R O E$, which means that a larger firm performs better than small and medium-sized enterprises (SMEs) in CBM\&A activities. It is also true that the Chinese listed firms which are involved in, and do well in, CBM\&A activities are large firms such as Lenovo. The degree of prior international experience is significantly negatively associated with $R O E$, which means that the more international businesses a firm has, the more difficult it is for obvious beneficial effects on the firm's performance to be apparent. This finding backs up Eriksson et al. (1997), mentioned in the literature review, which finds that a higher degree of prior international experience results in higher costs associated with overseas businesses. The results obtained for the degree of prior international experience provides the insight that the success of CBM\&A activities does not depend on how many deals a firm makes, but how much effort it puts into a single target. Finally, the results of the GCS dummy indicate that it is true that a higher level of cultural proximity helps firms to create greater value after CBM\&As. 
Table 6 Total effects of operating performance and abnormal performance after CBM\&As

\begin{tabular}{|c|c|c|c|c|}
\hline & (1) & $(2)$ & (3) & (4) \\
\hline Variables & $R O E$ & $R O E$ & $\mathrm{a} R O E$ & $\mathrm{a} R O E$ \\
\hline \multirow{2}{*}{$P M A$} & $-0.0728^{* * *}$ & $-0.0813^{* * *}$ & $-0.0724^{* * *}$ & $-0.0809 * * *$ \\
\hline & $(0.0183)$ & $(0.0195)$ & $(0.0183)$ & $(0.0195)$ \\
\hline \multirow{2}{*}{$E O$} & & -0.0854 & & -0.0864 \\
\hline & & $(0.125)$ & & $(0.125)$ \\
\hline \multirow{2}{*}{ PMA_EO } & & 0.204 & & 0.206 \\
\hline & & $(0.170)$ & & $(0.170)$ \\
\hline \multirow{2}{*}{ Acquirer Age } & -0.00108 & -0.000990 & -0.00110 & -0.00101 \\
\hline & $(0.00163)$ & $(0.00163)$ & $(0.00163)$ & $(0.00163)$ \\
\hline \multirow{2}{*}{ Acquirer Size } & $0.0177^{* * *}$ & $0.0177^{* * *}$ & $0.0177^{* * *}$ & $0.0176^{* * *}$ \\
\hline & $(0.00557)$ & $(0.00558)$ & $(0.00557)$ & $(0.00558)$ \\
\hline \multirow{2}{*}{$\begin{array}{l}\text { Degree of prior } \\
\text { international experience }\end{array}$} & $-0.0712^{* *}$ & $-0.0730^{* *}$ & $-0.0714^{* *}$ & $-0.0732^{* *}$ \\
\hline & $(0.0292)$ & $(0.0293)$ & $(0.0292)$ & $(0.0293)$ \\
\hline \multirow{2}{*}{ TMT Age } & 0.000723 & 0.000608 & 0.000723 & 0.000608 \\
\hline & $(0.00218)$ & $(0.00218)$ & $(0.00218)$ & $(0.00218)$ \\
\hline \multirow{2}{*}{ TMT Stock Option } & 0.0896 & 0.0906 & 0.0889 & 0.0899 \\
\hline & $(0.0691)$ & $(0.0693)$ & $(0.0691)$ & $(0.0693)$ \\
\hline \multirow{2}{*}{$\begin{array}{l}\text { Greater China plus } \\
\text { Singapore Dummy }\end{array}$} & $0.0528^{*}$ & $0.0524^{*}$ & $0.0528^{*}$ & $0.0524^{*}$ \\
\hline & $(0.0295)$ & $(0.0295)$ & $(0.0295)$ & $(0.0295)$ \\
\hline \multirow{2}{*}{ Constant } & -0.0390 & -0.0305 & -0.125 & -0.116 \\
\hline & $(0.103)$ & $(0.103)$ & $(0.103)$ & $(0.103)$ \\
\hline Observations & 1,567 & 1,567 & 1,567 & 1,567 \\
\hline R-squared & 0.021 & 0.021 & 0.020 & 0.021 \\
\hline
\end{tabular}

Note: Standard errors in parentheses, ${ }^{* * *} \mathrm{p}<0.01,{ }^{* *} \mathrm{p}<0.05,{ }^{*} \mathrm{p}<0.1$

In order to test whether the results are affected by the stock market, we define abnormal ROE based on Barber and Lyon (1996) detecting abnormal operating performance. The abnormal ROE of firm $i$ in year $t, \mathrm{a} R O E_{i t}$, is defined as $R O E_{i t}$ minus expected performance, $E\left(R O E_{i t}\right)$ :

$$
\begin{gathered}
\mathrm{a} R O E_{i t}=R O E_{i t}-E\left(R O E_{i t}\right) \\
E\left(R O E_{i t}\right)=a_{i}+\beta_{i} R O E_{\mathrm{m} t}
\end{gathered}
$$

$R O E_{\mathrm{m} t}$ is the average $R O E$ for each year for the market as a whole. Therefore,

$$
\mathrm{a} R O E_{i t}=R O E_{i t}-\left(a_{i}+\beta_{i} R O E_{\mathrm{m} t}\right)
$$


From columns (3) and (4) of Table 6 it can be seen that the total effects of abnormal ROE do not differ much from the results for $R O E$.

We then divide all the sample data into different industry groups using the US two-digit SIC codes and run the two regression models to explore Chinese listed firms' CBM\&A activities in more detail. We find that not all of the results for the industry sectors are the same as the effects for the sample as a whole. For example, the moderating effects of $E O$ are significant within some industries. Table 7 and Table 8 display the firms' results by different industry groups which have significant moderating effects; those which produce the same results as the sample as a whole or which have no significant effects are excluded.

Table 7 Results for different industry groups which have significant moderating effects (Metal mining industry, Primary Metal industry and Business Services industry)

\begin{tabular}{|c|c|c|c|c|c|c|}
\hline & \multicolumn{2}{|c|}{ Metal Mining } & \multicolumn{2}{|c|}{ Primary Metal Industry } & \multicolumn{2}{|c|}{ Business Services } \\
\hline Variables & $R O E$ & $\mathrm{aROE}$ & $R O E$ & $\mathrm{aROE}$ & $R O E$ & $\mathrm{aROE}$ \\
\hline \multirow{2}{*}{$P M A$} & $-0.112^{* * *}$ & $-0.113^{* * *}$ & -0.00522 & -0.00456 & -0.0364 & -0.0362 \\
\hline & $(0.0259)$ & $(0.0254)$ & $(0.0218)$ & $(0.0217)$ & $(0.0227)$ & $(0.0227)$ \\
\hline \multirow{2}{*}{$E O$} & $-1.462^{* *}$ & $-1.457^{* *}$ & 0.126 & 0.119 & $-0.845^{\star * *}$ & $-0.841^{* * *}$ \\
\hline & $(0.563)$ & $(0.552)$ & $(0.286)$ & $(0.285)$ & $(0.225)$ & $(0.224)$ \\
\hline \multirow{2}{*}{ PMA_EO } & $1.256^{*}$ & $1.263^{*}$ & $-1.350 * * *$ & $-1.353^{* * *}$ & $0.986^{* * *}$ & $0.984^{* * *}$ \\
\hline & $(0.705)$ & $(0.691)$ & $(0.358)$ & $(0.358)$ & $(0.259)$ & $(0.259)$ \\
\hline \multirow{2}{*}{ Acquirer Age } & 0.00327 & $0.00326^{*}$ & $-0.00674^{* * *}$ & $-0.00681^{* * *}$ & $-0.00473^{* *}$ & $-0.00470^{* *}$ \\
\hline & $(0.00195)$ & $(0.00192)$ & $(0.00166)$ & $(0.00165)$ & $(0.00214)$ & $(0.00214)$ \\
\hline \multirow{2}{*}{ Acquirer Size } & 0.0147 & 0.0152 & $0.0180^{* * *}$ & $0.0180^{* * *}$ & 0.00545 & 0.00552 \\
\hline & $(0.0205)$ & $(0.0201)$ & $(0.00546)$ & $(0.00545)$ & $(0.0113)$ & $(0.0113)$ \\
\hline \multirow{2}{*}{$\begin{array}{c}\text { Degree of prior } \\
\text { international experience }\end{array}$} & -0.0739 & -0.0715 & 0.00118 & 0.000755 & $-0.154^{*}$ & $-0.156^{*}$ \\
\hline & $(0.0793)$ & $(0.0778)$ & $(0.0420)$ & $(0.0419)$ & $(0.0845)$ & $(0.0845)$ \\
\hline \multirow{2}{*}{ TMT Age } & $-0.0116^{* * *}$ & $-0.0115^{* * *}$ & $-0.00561^{* *}$ & $-0.00565^{\star *}$ & -0.00486 & -0.00482 \\
\hline & $(0.00259)$ & $(0.00254)$ & $(0.00221)$ & $(0.00221)$ & $(0.00343)$ & $(0.00343)$ \\
\hline \multirow{2}{*}{ TMT Stock Option } & $103.3^{* * *}$ & $100.8^{* * *}$ & -0.102 & -0.100 & $0.135^{\star *}$ & $0.135^{\star *}$ \\
\hline & $(34.34)$ & $(33.69)$ & $(0.140)$ & $(0.140)$ & $(0.0647)$ & $(0.0647)$ \\
\hline \multirow{2}{*}{$\begin{array}{l}\text { Greater China plus } \\
\text { Singapore Dummy }\end{array}$} & -0.0385 & -0.0363 & 0.0111 & 0.0124 & 0.00257 & 0.00363 \\
\hline & $(0.0405)$ & $(0.0398)$ & $(0.0450)$ & $(0.0449)$ & $(0.0419)$ & $(0.0418)$ \\
\hline \multirow{2}{*}{ Constant } & $0.533^{* * *}$ & $0.441^{* *}$ & $0.278^{* *}$ & $0.195^{*}$ & $0.406^{* *}$ & 0.317 \\
\hline & $(0.188)$ & $(0.185)$ & $(0.116)$ & $(0.116)$ & $(0.191)$ & $(0.190)$ \\
\hline Observations & 58 & 58 & 108 & 108 & 77 & 77 \\
\hline R-squared & 0.623 & 0.630 & 0.501 & 0.504 & 0.362 & 0.362 \\
\hline
\end{tabular}

Note: Standard errors in parentheses, ${ }^{* * *} \mathrm{p}<0.01,{ }^{* *} \mathrm{p}<0.05,{ }^{*} \mathrm{p}<0.1$ 
Table 8 Results for different industry groups which have significant moderating effects (Real Estate industry and Security and Commodity Brokers, Dealers, Exchanges and Services industry)

\begin{tabular}{|c|c|c|c|c|}
\hline \multirow[b]{2}{*}{ Variables } & \multicolumn{2}{|c|}{ Security And Commodity } & \multicolumn{2}{|c|}{ Real Estate } \\
\hline & $R O E$ & $\mathrm{a} R O E$ & $R O E$ & $\mathrm{a} R O E$ \\
\hline \multirow{2}{*}{$P M A$} & -0.143 & -0.140 & 0.260 & 0.262 \\
\hline & $(0.112)$ & $(0.112)$ & $(0.562)$ & $(0.561)$ \\
\hline \multirow{2}{*}{$E O$} & $0.705^{\star *}$ & $0.702^{* *}$ & $1.776^{*}$ & $1.772^{*}$ \\
\hline & $(0.304)$ & $(0.305)$ & $(0.964)$ & $(0.963)$ \\
\hline \multirow{2}{*}{ PMA_EO } & -0.413 & -0.444 & -17.71 & -17.50 \\
\hline & $(1.632)$ & $(1.641)$ & $(115.3)$ & $(115.2)$ \\
\hline \multirow{2}{*}{ Acquirer Age } & $0.0269 * *$ & $0.0267^{* *}$ & 0.0204 & 0.0203 \\
\hline & $(0.0103)$ & $(0.0103)$ & $(0.0196)$ & $(0.0196)$ \\
\hline \multirow{2}{*}{ Acquirer Size } & 0.00253 & 0.00264 & -0.0626 & -0.0617 \\
\hline & $(0.0289)$ & $(0.0290)$ & $(0.109)$ & $(0.109)$ \\
\hline \multirow{2}{*}{$\begin{array}{c}\text { Degree of prior } \\
\text { international experience }\end{array}$} & -0.0950 & -0.0856 & $-1.093^{* * *}$ & $-1.092^{* * *}$ \\
\hline & $(1.053)$ & $(1.057)$ & $(0.356)$ & $(0.356)$ \\
\hline \multirow{2}{*}{ TMT Age } & $-0.0532^{* * *}$ & $-0.0529 * * *$ & -0.0205 & -0.0205 \\
\hline & $(0.0160)$ & $(0.0161)$ & $(0.0237)$ & $(0.0236)$ \\
\hline \multirow{2}{*}{ TMT Stock Option } & $102.8^{*}$ & $101.3^{*}$ & -4.056 & -4.022 \\
\hline & $(55.40)$ & $(55.58)$ & $(4.302)$ & $(4.298)$ \\
\hline \multirow{2}{*}{$\begin{array}{l}\text { Greater China plus } \\
\text { Singapore Dummy }\end{array}$} & 0.118 & 0.118 & -0.349 & -0.350 \\
\hline & $(0.146)$ & $(0.146)$ & $(0.827)$ & $(0.827)$ \\
\hline \multirow{2}{*}{ Constant } & $1.237^{* * *}$ & $1.139 * *$ & 1.071 & 0.979 \\
\hline & $(0.806)$ & $(0.808)$ & $(1.223)$ & $(1.222)$ \\
\hline Observations & 50 & 50 & 45 & 45 \\
\hline R-squared & 0.342 & 0.338 & 0.288 & 0.288 \\
\hline
\end{tabular}

Note: Standard errors in parentheses, ${ }^{* * *} \mathrm{p}<0.01,{ }^{* *} \mathrm{p}<0.05,{ }^{*} \mathrm{p}<0.1$

It can be seen that, regardless of whether the dependent variable is $R O E$ or abnormal $R O E$, the results for the two kinds of models are similar, while different industries have their own characteristics. In the metal mining and the business services industries, the effect of the moderating variable $E O$ is overall significantly negative for operating performance. However, after CBM\&A has taken place, the interaction with the independent variable has a significantly positive effect on the firm's performance. This means that, after acquisition, a firm with a higher degree of EO improves its performance post-CBM\&A (PMA) to some extent. In other words, after this kind of firms become international firms, those which have a good and higher sense of $E O$ will improve their business performances. For example, after Didi Taxi acquired Uber China, the new service products helped the post-acquired Didi's performance improve much. In the security and commodity brokers, dealers, exchanges and services industry and the real estate industry, the interaction of $E O$ with $P M A\left(E O^{*} P M A\right)$ is not significant, but $E O$ is significantly positively related to firms' operating performance, which means that a higher degree of $E O$ can improve Chinese listed firms' 
performance in the long run and does not interact with CBM\&A activities. In the primary metal industry, $E O$ is not related to firms' performance and the interaction with PMA is significantly adverse, because it is a primary industry that is different from other industries. This indicates that $E O$ weakens the firms' operating performance after CBM\&As in this industry, and that CBM\&As have no effect on the firms' operation in this industry either.

The control variable, acquirer age, is positively related to firms' performance in the metal mining industry, but only the effect on abnormal ROE is significant at the $10 \%$ level of confidence and the coefficient is very small $(0.0033$, which is nearly equal to zero), so the effect can be ignored. In the security and commodity industry, the acquirer age is positively related to the firm's performance too, and the effects on both models are significant, which means that older firms are better at dealing with CBM\&A activities and are more experienced at improving their performance. However, in the primary metal industry and business services industry, the coefficients for acquirer age are significant and negative in both models, but are smaller than 0.007 , which means that relatively younger firms have more incentives to improve their acquisition performance but the effect is not strong. In the primary metal industry, acquirer size is significantly positive in terms of performance, which is consistent with the results for the sample as a whole. The results for internationalization in the real estate industry and the business services industry are consistent with those of the sample as a whole too, which is significantly negative for firms' performance. Those industries which have significant results for the TMT age are all negative regarding the performance, and those which have significant results for the TMT stock option are all positive in performance terms, which means that in these industries a younger TMT or a management team with a larger share of stock options will help to improve the acquisition performance. These findings are consistent with those of previous studies.

Overall, firms in different industries have their own characteristics. Although the results for the whole sample show that CBM\&A activities cannot improve firms' operating performance within the sample periods, $E O$ can have positive effects or positive interaction with CBM\&A activities in some industries, indicating that the latter may help acquirers to get used to the new post-acquisition situation, and ultimately improve their performance. Given that most Chinese firms' CBM\&A deals are made with developed countries (Figure 2), the ensuing adjustment and learning process is bound to be long.

\section{Discussion and Conclusion}

Against the background that China encourages its domestic firms to go overseas, especially those countries and regions involved in its "Belt and Road Initiative", and under a favorable environment for innovation and entrepreneurship, this paper is a first trial to test whether Chinese firms' operating performance changes after CBM\&As, using $E O$ as a moderating factor. After combining Chinese listed firms' annual reports, Chinese stock market financial statements database and the Zephyr database from 2001 to 2015, this paper examines how acquirers' operating performance changed after CBM\&As, using $E O$ as a moderating factor to test whether firms' performance is affected by differing degrees of $E O$ during CBM\&As. The results for the sample as a whole show that the trends in the performance of Chinese listed firms are fluctuant after CBM\&As within the sample years. Performance increases one year after the acquisition but drops two years later and then follows an increasing trend, and the moderating factor of $E O$ is not significant for the entire sample. After the sample is divided into different industry groups, it becomes clear that different industries have their own characteristics. For example, EO helps 
Chinese listed firms to adjust to the post-acquisition situation and even to improve their performance to some extent in the metal mining industry and the business services industry. When we substitute $R O E$ with abnormal $R O E$, the results do not change much.

One suggestion that can be made for the benefit of Chinese firms' CBM\&As is that although the Chinese government are encouraging domestic firms to "go out" and acquire overseas companies, they need to reconsider whether a firm can cope with the issues involved before taking action, in terms of the distinctive features of the industry sector in which it operates, as well as the firm's organizational characteristics and corporate governance characteristics. Moreover, they need to think about the cultural distance with the target company and to be aware of the adjustment period after a CBM\&A. EO is a strong motivation which combines two aspects that firms are keen to pursue: research and development orientation and investment orientation. However, whether or not $E O$ will have a positive moderating effect is dependent on a firm's own operating situation and industry environment. Therefore, Chinese firms need to be cautious and thorough when they are making decisions about overseas M\&As, especially when the target enterprise is in a developed country. As the operating performance is fluctuant, they also need to be well prepared for the adjustment period after the CBM\&A deal has been done.

Possible plans for further study are as follows. Firstly, we would like to use cross-sectional data to test the short-term effect of CBM\&As with a moderating variable of $E O$, although we have stated in the former sections that the Chinese capital market is still not efficient so the stock prices of Chinese listed firms can not represent a firm's performance very accurately. We will try to use daily stock returns of Chinese listed firms which are involved in CBM\&A activities to calculate the CAR of each firm and use it as a dependent variable to test a few days before and after the announcement of a CBM\&A, so as to examine the moderating effect caused by $E O$ in the short term. Another way in which the current study could be modified is that we would like to try to use other financial indicators of firms' operating performance, such as ROA, to test existing models, although ROE used in this paper is the most suitable index for the Chinese security market, as previously stated.

\section{References}

Ahuja, G., Morris Lampert, C., 2001. Entrepreneurship in the large corporation: A longitudinal study of how established firms create breakthrough inventions. Strategic management journal, 22(6-7), 521-543.

Barber, B. M., Lyon, J. D., 1996. Detecting abnormal operating performance: The empirical power and specification of test statistics. Journal of financial economics, 41(3), 359-399.

Bhaumik, S., Driffield, N., Gaur, A. S., et al., 2019. Corporate governance and MNE strategies in emerging economies. Journal of World Business, 54(4), 234-243.

Boateng, A., Wang, Q., Yang, T., 2008. Cross-border M\&As by Chinese firms: An analysis of strategic motives and performance. Thunderbird International Business Review, 50(4), 259-270.

Datta, D. K., Puia, G., 1995. Cross-border acquisitions: An examination of the influence of relatedness and cultural fit on shareholder value creation in US acquiring firms. MIR: Management International Review, 35(4), 337-359.

Davies, K., 2009. While global FDI falls, China's outward FDI doubles. Transnational Corporations Review, 1(4), 2023.

Dickerson, A. P., Gibson, H. D., Tsakalotos, E., 1997. The impact of acquisitions on company performance: Evidence from a large panel of UK firms. Oxford Economic Papers, 49(3), 344-361.

Eriksson, K., Johanson, J., Majkgard, A., et al., 1997. Experiential knowledge and cost in the internationalization process. Journal of international business studies, 28(2), 337-360.

Fornes, G., Lopez, B., de Haan, M. B., et al., 2019. Best practice example of CSR and SandE engagement in emerging economies: analysis of a case study based in China. Journal of Asia Business Studies, 13(1), 133-154. 
Gaur, A., Ma, H., Ge, B., 2019. MNC strategy, knowledge transfer context, and knowledge flow in MNCs. Journal of Knowledge Management, 23(9), 1885-1900.

Gugler, K., Mueller, D. C., Yurtoglu, B. B., et al., 2003. The effects of mergers: an international comparison. International journal of industrial organization, 21(5), 625-653.

Hambrick, D. C., Fukutomi, G. D., 1991. The seasons of a CEO's tenure. Academy of management Review, 16(4), 719-742.

Hedlund, G., 1986. The hypermodern MNC - a heterarchy? Human resource management, 25(1), 9-35.

Jantunen, A., Puumalainen, K., Saarenketo, S., et al., 2005. Entrepreneurial orientation, dynamic capabilities and international performance. Journal of International Entrepreneurship, 3(3), 223-243.

Jensen, M. C., Murphy, K. J., 1990. Performance Pay and Top-Management Incentives. Journal of political economy, 98(2), 225-264.

Knight, G. A., 2001. Entrepreneurship and strategy in the international SME. Journal of international management, 7(3), 155-171.

Kogut, B., Singh, H., 1988. The effect of national culture on the choice of entry mode. Journal of international business studies, 19(3), 411-432.

Li, J., Li, P., Wang, B., 2016. Do cross-border acquisitions create value? Evidence from overseas acquisitions by Chinese firms. International Business Review, 25(2), 471-483.

Luedi, T., 2008. China's track record in M\&A: China's companies are expanding the focus of their outbound M\&A, but so far they have struggled to create value. McKinsey Quarterly, 3, 75.

Lumpkin, G. T., Dess, G. G., 1996. Clarifying the entrepreneurial orientation construct and linking it to performance. Academy of management Review, 21(1), 135-172.

Martynova, M., Renneboog, L., 2008. A century of corporate takeovers: What have we learned and where do we stand? Journal of Banking and Finance, 32(10), 2148-2177.

Mason, C. H., Perreault Jr, W. D., 1991. Collinearity, power, and interpretation of multiple regression analysis. Journal of marketing research, 28(3), 268-280.

Mei, L., 2009. Empirical Study on Financial Performance of Chinese Listed Companies in Cross-border M\&A [J]. Technology Economics, 28(12), 83-87.

Ravenscraft, D. J., Scherer, F. M., 2011. Mergers, sell-offs, and economic efficiency. Washington DC: Brookings Institution Press.

Sharma, S., Durand, R. M., Gur-Arie, O., 1981. Identification and analysis of moderator variables. Journal of marketing research, 18(3), 291-300.

Shenkar, O., 2001. Cultural distance revisited: Towards a more rigorous conceptualization and measurement of cultural differences. Journal of international business studies, 32(3), 519-535.

Shenkar, O., 2012. Beyond cultural distance: Switching to a friction lens in the study of cultural differences. Journal of international business studies, 43(1), 12-17.

Shenkar, O., Luo, Y., 2008. International Business (With Cd). New Jersey: John Wiley and Sons.

UNCTAD, 2003. FDI policy for development: national and international perspectives. World Investment Report 2003, New York and Geneva: United Nations.

UNCTAD, 2013a. Value of Cross-Border M\&A by Region/Economy of Purchasers (1990-2012). Retrieved 2015/1/30, from http://unctad.org/Sections/dite_dir/docs/WIR2013/WIR13_webtab10.xls

UNCTAD, 2011. World investment report 2011. United Nations Publication.

UNCTAD, 2013b. Investment and Trade for Development. World Investment Report.

Wiklund, J., Shepherd, D., 2003. Knowledge-based resources, entrepreneurial orientation, and the performance of small and medium - sized businesses. Strategic management journal, 24(13), 1307-1314.

Williams, C., Lee, S. H., 2009. Resource allocations, knowledge network characteristics and entrepreneurial orientation of multinational corporations. Research Policy, 38(8), 1376-1387.

Wu, C., Xie, N., 2010. Determinants of cross-border merger and acquisition performance of Chinese enterprises. ProcediaSocial and Behavioral Sciences, 2(5), 6896-6905.

Zahra, S. A., Garvis, D. M., 2000. International corporate entrepreneurship and firm performance: The moderating effect of international environmental hostility. Journal of business venturing, 15(5), 469-492. 